\title{
Carpet-bombing the colon is bad
}

\author{
Alden H. Harken, MD, FACS
}

From the Department of Surgery, University of California, San Francisco-East Bay, Oakland, Calif. Disclosures: Author has nothing to disclose with regard to commercial support.

Received for publication Sept 19, 2017; accepted for publication Sept 25, 2017; available ahead of print Oct 25, 2017.

Address for reprints: Alden H. Harken, MD, FACS, Department of Surgery, University of California, San Francisco-East Bay, 1411 E 31st St (QIC 22134), Oakland, CA 94602 (E-mail: alden.harken@ucsfmedetr.org). J Thorac Cardiovasc Surg 2018;155:659

$0022-5223 / \$ 36.00$

Copyright (C) 2017 by The American Association for Thoracic Surgery

https://doi.org/10.1016/j.jtcvs.2017.09.117

The important article by Kirkwood and colleagues ${ }^{1}$ in this issue of the Journal analyzes the "incidence and severity of Clostridium difficile infections" from data found in the Cardiothoracic Surgical Trials Network. The frustrating observation is that the incidence of $C$ difficile is increasing, and the subtext question is this: Is this our fault? We have all had patients with deep sternal wound infections, and we will mount almost any measure to avoid this dread complication. Unlike a hole poked in the undersurface of the transverse arch during a redo, the pain of a deep sternal wound infection can linger and punish for weeks. So we blast the patient with antibiotics.

The consensus recommendation for antibiotic prophylaxis surrounding cardiac surgery is to infuse second- or third-generation cephalosporins 30 to 60 minutes before the skin incision and for 24 to 48 hours after the operation. ${ }^{2}$ Now, my high school science teacher told me several unbelievable things about my gastrointestinal tract: (1) that the inside of my colon is outside my body; (2) that there are 10 times more bacteria in my colon than cells in my body; and (3) that with a doubling time of around $20 \mathrm{mi}-$ nutes, the progeny of a single Escherichia coli with an unlimited food supply could assume the mass of the earth within 24 hours. So, inside us all, Malthusian population control is very healthy. When a surgeon disrupts this natural war of the hundreds of bacterial species fighting for survival, we are not yet very good at exclusively targeting the bacterial terrorists. Many bacterial species favorably compete with the bad guys and even help us digest. Indeed, fecal microbiota transplantation (sharing stool with a friend) is a safe, inexpensive, and effective cure for $C$ difficile in more than $90 \%$ of cases. ${ }^{3}$

Interestingly, in the study of Kirkwood and colleagues, ${ }^{1}$ the percentages of patients with and without $C$ difficile did not differ in receiving first-generation cephalosporins

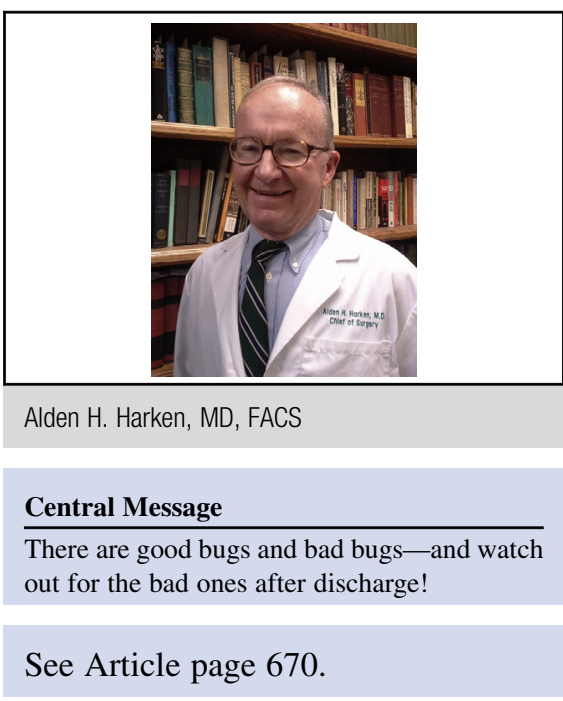

(46\% vs $36 \%$ ), second-generation cephalosporins $(26 \%$ vs $43.7 \%$ ), and "other" agents, presumably vancomycin, specific for $C$ difficile ( $28 \%$ vs $20.3 \%$ ). The specific antibiotic regimen that was used - the duration, however, did.

Our preoperative antibiotic prophylaxis is still at the stage of indiscriminately carpet-bombing the colon. The article by Kirkwood and colleagues ${ }^{1}$ confirms several counterintuitive surgical observations: (1) unlike the single-dose antibiotic prophylaxis recommended for general surgical procedures, 24 to 48 hours of antibiotic coverage appears superior in cardiac patients; (2) "bigger" (further prolongation of antibiotic coverage) is not better; (3) indeed, extended antibiotic coverage is bad; (4) hyperglycemia just feeds the pathogenic bacteria; and (5) surprisingly, approximately half of the cases of $C$ difficile were seen after discharge_-so keep watching.

\section{References}

1. Kirkwood KA, Gulack BC, Iribarne A, Bowdish ME, Greco G, Mayer ML, et al A multi-institutional cohort study confirming the risks of Clostridium difficile infection associated with prolonged antibiotic prophylaxis. J Thorac Cardiovasc Surg. 2018;155:670-8.e1.

2. Kappeler R, Gillham M, Brown NM. Antibiotic prophylaxis for cardiac surgery J Antimicrob Chemother. 2012;67:521-2.

3. Bakken JS, Borody T, Brandt LJ, Brill JV, Demarco DC, Franzos MA, et al; Fecal Microbiota Transplantation Workgroup. Treating Clostridium difficile infection with fecal microbiota transplantation. Clin Gastroenterol Hepatol. 2011;9:1044-9. 